\title{
Article
}

\section{Emotions, Play and Graduate Student Writing}

\author{
Cecile M. Badenhorst ${ }^{1}$
}

Faculty of Education, Memorial University

\begin{abstract}
While playfulness is important to graduate writing to shift students into new ways of thinking about their research, a key obstacle to having fun is writing anxiety. Writing is emotional, and despite a growing field of research that attests to this, emotions are often not explicitly recognized as part of the graduate student writing journey. Many students experience writing anxiety, particularly when receiving feedback on dissertations or papers for publication. Feedback on writing-in-progress is crucial to meeting disciplinary expectations and developing a scholarly identity for the writer. Yet many students are unable to cope with the emotions generated by criticism of their writing. This paper presents pedagogical strategies-free-writing, negotiating negative internal dialogue, and using objects to externalize feelings-to help students navigate their emotions, while recognizing the broader discursive context within which graduate writing takes place. Reflections on the pedagogical strategies from nineteen Masters and PhD students attending a course, Graduate Research Writing, were used to illustrate student experiences over the semester. The pedagogical strategies helped students to recognize their emotions, to make decisions about their emotional reactions and to develop agency in the way they responded to critical feedback. By acknowledging the emotional nature of writing, students are more open to creativity, originality, and imagination.
\end{abstract}

\section{Introduction}

Play and creativity are vital components of the graduate student research writing courses I teach (Badenhorst, Moloney, Dyer, Rosales \& Murray, 2015). They are important because academic writing and research practices are shaped by the specific norms of particular disciplinary discourses. 
Volume 28, 2018

http://journals.sfu.ca/cjsdw

Introducing a playful element ruffles students, shakes them up and opens their eyes to the taken-forgranted world of academic writing. Most students learn how to write in their disciplines by following the rules. They learn, for example, what questions can be asked, what can be written and who can be cited. Thinking playfully and deeply provides the space for students to step outside of the rules in their thinking and to explore their research differently. Rather than ventriloquizing their disciplines (Fulford, 2009), they shift into making conscious choices-albeit within broader constraints-about the research writing they want to produce and the scholars they want to be. Playfulness produces the space for them to negotiate the tension of working within a system while thinking outside of it. Yet a key obstacle to working with playfulness is writing anxiety. It is extremely difficult to have fun, be playful, or even think innovatively when one is agitated by the task and fearful of the consequences. For this reason, I would like to address writing anxiety specifically, and the emotional nature of writing more broadly in this paper. I offer my pedagogical strategies to help students deal with their individual emotions within a broader context that seems to engender stress and concern, and show through research conducted in my course how students experienced this engagement with the pedagogy. I argue that there is still room for playfulness if one is mindful about student anxiety.

\section{Critical Feedback, Writing Anxiety and Emotional Intelligence}

Graduate Research Writing is a 4-month semester-long credit-bearing course that I developed and teach at a mid-size Canadian university. Although housed in the Faculty of Education, the course is open to masters and doctoral students from all disciplines. The course covers the nature of knowledge, academic discourses, writing processes, academic genres, rhetorical strategies, and disciplinary knowledge in thesis writing and research publication (for further accounts of the pedagogy see: Badenhorst, Moloney, Rosales \& Dyer, 2012; 2016; Badenhorst, Moloney, Rosales, Dyer \& $\mathrm{Ru}, 2016)$. I have taught the course for three iterations and have noted that-generallythree groupings of students tend to register: 1) multilingual students whose supervisors have recommended they complete the course to improve their language skills; 2) students who have had successful writing/publishing careers in that they won early awards for theses or publications but now find themselves stuck; and 3) students who are long over-due on their dissertations, are ready to quit, but have decided to do the course as a final effort. All students are dedicated, hard-working, and intellectually at the top of their game. Many take this course in addition to their regular courseload, teaching and work commitments. The one striking commonality is that they are all highly 
critical of themselves and their writing. This self-criticism is often crippling and many students become too paralysed to write. Those students struggling with academic English are highly critical of their 'errors' even though many of them hold prestigious grants, the bright-stars are fearful that they may never shine again, and the long-term students on some level do not believe they can complete this degree.

Students in the course articulated their writing anxieties in the first assignment they complete. One student, Anson², for example, described his professor holding up the "worst" papers and publicly handing them out until Anson was given his paper-the worst of the worst. Other students described highly emotional occasions as well:

I was called [in] by my professor and he said that my submission was the worst that he had ever read. (Carson)

My supervisor was NEVER EVER happy about my writing. He always used a red pen and crossed out almost eighty percent of my writing and his only comment was: YOU DO NOT MAKE ANY SENSE! I cried almost every time after my meeting with him. I felt frustrated and did not have any tips or guidance to improve my writing. (Blaine, emphasis in original)

During my academic studies writing has become incredibly, emotionally painful...I've received a lot of criticism, a lot of discouragement, a lot of "bruising," negative comments that may have deterred [another] student to quit and never return. (Via)

The consequences of these negative emotions were procrastination, avoidance, writer's block, and general writing anxiety, as these excerpts below show:

Sometimes I feel physically sick (nauseous, shaky and a racing heartbeat) sitting in front of the computer, my creativity and confidence temporarily destroyed. Other times I spend hours rewriting a paragraph, trying to achieve perfection in my voice...Over the last few months, I started to seriously question if I was capable of finishing the Ph.D (Amari).

I get tense, depressed and feel uncomfortable whenever I have to submit my assignments (Blaine).

I have spent days and days in front of my computer without writing a word (Harley). 
Volume 28, 2018

http://journals.sfu.ca/cjsdw

\section{Critical feedback}

Although students are anxious about many issues, including financial deprivation, the experience of being an international student, managing childcare, and others, in terms of writing, students identified feedback on writing as one of their key sources of anxiety. Many students, naturally, take critique (critical review) and criticism (finding fault) on their writing personally. Critical feedback assumes personal meaning for students because they feel that the feedback could validate their worth or undermine their self-esteem. There is huge emotional investment in writing feedback and for some students their whole sense of self is at stake (Caffarella \& Barnett, 2000; Young, 2000). Yet feedback, particularly from supervisors, is an essential part of formative assessment for graduate students in their writing and in shaping their identity as scholars (Friedrich-Nel, \& MacKinnon, 2015). Feedback is often fundamental to learning, and to producing appropriate quality writing. It is also frequently problematic.

Supervisory feedback constitutes the main form of pedagogy for students writing a thesis and supervisors are pivotal in students learning how to write $(\mathrm{Xu}, 2016)$. As Paré, Starke-Meyerring \& McAlpine (2011) expressively note: "In this high-stakes, intimate tutorial-possibly the most crucial educational relationship of a student's life-new scholars are initiated into the process of making disciplinary knowledge through writing" (p.59). Despite this significant role, supervisors are rarely trained to provide writing support, and in the absence of professional development, they tend to reproduce their own, often flawed, supervision processes (Doloriert, Sambrook, \& Stewart, 2012; Paré, 2011; Williams \& Lee, 1999). Despite being a means for support, supervisors sometimes end up constraining their students' intellectual development (McAlpine, Paulson, Gonsalves \& JazvacMartek, 2012). While many supervisors are engaged and encouraging, some micro-manage and are hyper-critical, and others are intellectually absent and unsupportive. Consequently, many supervisory practices around writing leave students hurt and disillusioned (Aitchison, Catterall, Ross \& Burgin, 2012). Värlander (2008) shows the consequences of flawed supervisory practices; if the supervisory relationship is hierarchical or authoritarian, and the feedback is transmitted rather than negotiated there are emotional risks for the student (Värlander, 2008). Xu (2016) also suggests that negotiated feedback initiates student agency but overly critical feedback encourages passivity. Resultant anxiety on the part of the student can lead to students "passively participat[ing]" in the writing process without a sense of agency or ownership (Maher, Feldon, Timmerman, \& Chao, 2014, p. 704). When feedback is in line with the student's goals, positive emotions can result but when 
feedback obstructs these goals, negative emotions emerge. Feedback that is unexpected, or when students are unsure what went wrong, can also result in anger or uncertainty (Rowe, Fitness \& Wood, 2014). The way students get feedback, what they value, and what they do with it are all shaped by emotions (Caffarella \& Barnett, 2000; Värlander, 2008; Wellington, 2010).

\section{Writing anxiety}

Despite the acknowledged prevalence of writing anxiety in the research literature, many students feel it is risky to express these emotions in academic communities. There is the danger of the gendering of emotion as feminine, and that when women talk about emotion it confirms that they are not emotionally up to the task required (Hey, 2011). For both men and women, having writing anxiety and expressing emotions is often taken as an indicator of an inability to cope with the pressures rather a normal part of the process. Aitchison, et al. (2012), in their study of science doctoral students, reveal that supervisors felt that if students could not take critique, they should not be doing a PhD. They also showed how supervisors often expressed frustration, irritation and even anger at student writing while advocating that these emotions were not personal but a form of 'tough love.' Aitchison et al. (2012), state: "in this study participants frequently used terms such as, 'tough love,' 'sink or swim' and 'trial and error' when referring to experiences of learning or teaching research writing" (p. 444). Emotional toughness is seen as a normal part of academic culture yet students are rarely shown how to cope or to analyse the roots of these emotions.

Yet, feelings of worry, fear or panic are real experiences for many graduate students and while emotions are experienced individually, broader contextual conditions often provide the substrate for stressful emotions. Three of these conditions are highlighted here: first, writing is a high-stakes activity because completion of degrees and future career paths are dependent on success in dissertation writing and research publishing (Kamler, 2008). Writing is the key vehicle for participating in disciplinary conversations, for accessing research funds and for progressing in an academic career. The consequences of not being successful are high and contribute to feelings of anxiety around failing; second, writing practices in academic contexts are mostly invisible and form a large part of the tacit knowledge of entrenched discourse community members (Bosanquet \& Cahir, 2016; Paré, et al., 2011). Graduate students, who are newcomers, may spend many years of trial and error trying to learn the implicit literacies of successful research writing. This murky world of tacit assumptions, unseen disciplinary requirements, and hidden ideological allegiances create the 
Volume 28, 2018

http://journals.sfu.ca/cjsdw

conditions for misunderstandings, apprehension, and anxiety; third, embedded in writing practices are identity-formation processes. Through writing, doctoral students learn how to position themselves, engage in disciplinary conversations and become members in discourse communities (Aitchison, et al., 2012; Barnacle \& Mewburn, 2010). Powerful emotions arise because these processes are often contradictory as a consequence of traversing the trajectories of novice/expert, outsider/insider and other identity-work (Aitchison \& Mowbray, 2013; Searr \& McClean, 2008). As Kamler and Thompson (2006) suggest: "the text is an extension of the scholar, a putting of 'self' out there which is either successful-or not" (p. 15). Rejection of a text is linked to the rejection of the scholar writer because writing is closely tied to a sense of self. Novices feel vulnerable because when they send a text out for review they are sending themselves out, as scholars, for review as well (Kamler, 2008). The text is the place where the graduate student believes s/he will be judged and found wanting.

\section{Discursive emotional intelligence}

The negative impact of writing anxiety is also well documented. High attrition rates are linked to writing anxiety (Stubb, Pyhältö, \& Lonka, 2011); students writing in English as an additional language experience high levels of writing stress (Huerta, Goodson, Beigi \& Chlup, 2017); and anxiety leads to low self-efficacy, procrastination and writer's block (Lavalle \& Bushrow, 2007; Onwuegbuzie \& Collins, 2001). Publication related anxiety—being rejected or being exposed as inadequate-is quite common among doctoral students (Kamler, 2008). Women, particularly, are likely to have more writing anxiety than men in higher education contexts (Huerta, et al., 2017; Martinez, Kock \& Cass, 2011; Stubb et al., 2011) and often experience greater isolation, or feelings of not belonging to academic cultures (Brown \& Watson, 2010).

How do we help students negotiate writing anxiety? How do we encourage students to handle critical feedback? How do we mediate comments such as: students need to accept "what other people have to say about [their] work without taking it personally;" or deal with feedback that is not "sugarcoated;" or cope with the "harsh reality check" in a supervisor's comments? (Collins, 2015, p. 53). In my classes, I turn to emotional intelligence.

Emotional intelligence-the individual ability to monitor one's own emotions strategically-is the learned ability to self-assess and regulate emotions, particularly anxiety (Goleman, 1997). Despite being rooted in popular psychology, the principles of emotional intelligence have been applied in 
Volume 28, 2018

http://journals.sfu.ca/cjsdw

higher education contexts, particularly in relation to writing anxiety (Huerta, et al., 2017). While I am aware that the validity of emotional intelligence is contested in academic contexts, it provides me with a language to discuss emotions since most students have heard of the concept. With emotional intelligence, students would ask themselves: What is the emotion I'm experiencing? Why am I experiencing this emotion? What can I do to manage it?

However, despite its usefulness in creating the classroom space for broaching emotions, emotional intelligence is an uncomfortable fit for me because it places accountability squarely on the individual student and encourages perceptions of deficit. Students just need to "fix" themselves and "manage" their emotions and all will be well. The institutional and contextual pressures fade into the background. To understand this tension better, it is useful to visit Burford's (2017) summary of three conceptualisations of emotions in doctoral education research. The first way emotions are understood, is to frame emotions as a problem that "ought to be absent, or at least carefully managed, so as not to cause a disturbance to the doctoral experience" (Burford, 2017, p.22). Here, students are encouraged not to let emotions surface which privileges the idea of the independent rational scholar toiling away in isolation. Emotions are often perceived as a weakness and an obstruction to the objective knowledge of research (Aitchison \& Mowbray, 2013; Leathwood \& Hey, 2009; Wellington, 2010). This is the reality many students experience, so much so, that researchers are now recognizing that graduate students (and faculty) often experience emotional labour (Aitchison \& Mobray, 2013; Aitchison, et al., 2012; Cameron, Nairn \& Higgins, 2009). One way of understanding emotional labour is that it is a form of work where one hides unwanted emotions in an attempt to conform to a prevailing norm which can contribute to even higher levels of anxiety (Jarzabkowski, 2001).

The second conceptualization of emotions is a reaction to the first and constitutes a growing body of research in graduate research education. This conceptualization emphasizes that emotions are "necessary in the production of doctoral subjects" (Burford, 2017, p.23). Emotions are the natural outcome of the processes and struggles of graduate work and should be acknowledged as such (Cotterall, 2013; Bosanquet \& Cahir, 2016; Beard, Clegg \& Smith, 2007; Doloriert, et al., 2012; McAlpine, et al., 2012; Sawir, Marginson, Deumert, Nyland \& Ramia, 2008; Värlander, 2008). There is a recognition and that the embodied nature of graduate writing is important, and that some experiences in the doctoral journey generate more emotions than others. Both personal and collaborative strategies are offered as a way of managing emotions. 
Volume 28, 2018

http://journals.sfu.ca/cjsdw

The third approach to emotions is Burford's (2017) affective-politics, where he shifts the focus from the individual to the broader context. He argues that systemic pressures have created conditions of work intensification, time compression, career uncertainty, and job-prospect insecurity that have inevitably led to high levels of anxiety and stress among students. Writing anxiety, then builds from the pressures of having to succeed in these pressure-cooker circumstances. Burford (2017) critiques the role that "managing" emotions can play by arguing that by managing emotions we encourage students to become (impossible) perfect neo-liberal subjects.

I find myself straddling the latter two conceptualisations of emotions in graduate research education. To me, it is critical that students recognise the role emotions play in helping or hindering their writing but at the same time I want to mentor students as intentional subjects who can shape their own subject positions. To do this, they need to be able to see their positioning in the discourses around them. Emotional intelligence, then, is not a question of "managing" personal emotions to fit in, instead, it requires the student to see these emotions as both individual but also a result of broader systemic pressures. I have called this discursive emotional intelligence-a more nuanced tool than the available ways of talking about emotions. This is the ability to recognise and make decisions on the broader relations and pressures that appear individualistic but are often more systemic. In this way, we can view emotions as individual (emotional intelligence) but also as a consequence of wider systems of pressure (discursive) that are sometimes not obvious or apparent. Here students would ask: Am I at fault here? Do I need to take this emotion on? How do I negotiate this feeling? Discursive emotional intelligence helps students become aware of their positions of power within the discourse and make decisions about how to negotiate their positionality. In the next section, I describe how I present discursive emotional intelligence in the course.

\section{Pedagogical Strategies}

The emotional intelligence part of the course, like the other components (nature of knowledge, academic discourses, writing process, academic genres, rhetorical strategies, and disciplinary knowledge) is woven in throughout the semester. Students begin by writing Assignment A which is a literacy narrative. In this paper, they are asked to track their writing history, note significant moments, identify literacy brokers, and analyse their progress as a writer. While I am aware of the critiques that literacy narratives often perpetuate normative myths (Alexander, 2011), the purpose of this assignment was for students to begin noticing their own writing practices as being changeable 
Volume 28, 2018

http://journals.sfu.ca/cjsdw

and not fixed, and to begin recognising the social nature of writing in their own experiences. In Assignment B, they were required to conduct a discourse analysis of writing in their discipline, and model that writing. Assignment C was a portfolio assignment. With Emmons' (2003) critique of reflection-assignments in mind, students were encouraged to note their experiences of institutional and disciplinary expectations and contradictions. In the portfolio, students chose five sets (drafts to final product) of writing they had completed over the semester to illustrate their threshold concepts-significant learning 'moments' in the course. These writing sets were selected from those they had completed in class as well as items written as part of their programs during the semester, for example, conference abstracts, book chapter proposals, conference papers, papers for publication, thesis chapters, and so on. With the portfolio, they included a narrative to explain and analyse their selected writing. In addition, throughout the course, I asked students to think visually and to engage in playful activities that promote risk-taking and lateral thinking in their writing (see Badenhorst, et al., 2012)

During the course, emotions, criticism, and feedback are discussed openly and we hold both the personal and the institutional in uneasy tension throughout. I employ a number of pedagogical strategies to help students acknowledge the effect of their emotions on their writing. These strategies, while focusing on the individual, are set within a context of dialogue on broader discursive practices. First, I introduce students to Peter Elbow's (1981) free-writing technique. These are timed writing sessions where the writer writes expressively without correcting. They are encouraged to separate composition from editing and to keep their internal critical voice quiet during composing phases. Students write many free-writes in class and in their homework activities.

The second pedagogical strategy is to explicitly discuss how to deal with their negative internal dialogue and critical feedback generally. I introduce students to Maisel's Toxic Criticism (2007) and it is useful to explain this in detail here because, for many students, this is new knowledge. Maisel (2007) identifies three types of criticism: Actual (criticism you have received), anticipated (criticism you think you will receive) and self-criticism (internalised criticism). We also discuss fair and unfair criticism: fair criticism is where we agree with the criticism and unfair criticism is where we believe the criticism is unjust. He argues that both can be harmful mostly because they feed into a dominant internal critical voice. Maisel (2007) argues that understanding criticism is important because we need to make decisions on what to do and the consequences can be significant. In the class, we also discuss common reactions to criticism: avoidance, becoming angry and confrontational, feeling wounded, increased self-criticism, and self-sabotage among others (Maisel, 2007). We then discuss 
mechanisms for dealing with criticism. Maisel (2007) outlines six decisions that students can take: 1) An existential decision to decide that it is important to acknowledge emotions; 2) a decision to appraise the criticism and only take what is valuable; 3 ) a decision about attitude and not letting the criticism affect your mental state or moods; 4) a cognitive decision to control negative self-talk and to treat yourself with respect; 5) a personality decision where you respond to criticism in ways that do not weaken your sense of self; and finally, 6) a decision about behaviour, to take action to deal effectively with criticism, whatever form that might be. While the summary here focuses on the individual's experience, Maisel is aware that individuals work within contexts of constraint and is careful to question these constraints and boundaries. In class, over the semester, we talk about the viability of these decisions within the context of academia, what is negotiable, how much one can conform or resist, and what the consequences of each would be. My goal is not to impose strategies but for students to begin making decisions about what they want to do and how they want to go about it. I also ask students to watch Brené Brown's TED talk on vulnerability (2010) and Kristen Neff's one on self-compassion (2013). Both videos emphasize the importance of recognising emotions in the context of academia and highlight the need for self-compassion amid discourses that promote notions of competition and individual deficit.

The third strategy-using objects to externalize feelings - is an attempt to engage with playfulness and is one which often surprises students. I buy plastic toy cats from the dollar store and students choose a cat to keep near their computers or at their writing spaces (see Photo 1 ). The cat represents their internal critical voice or the critical voice of a supervisor. The toy helps them to externalise the voice that sometimes has become so internalised that they cannot hear how much they are criticising themselves. The object becomes an external aid that mediates activity (Prior \& Shipka, 2003). Using objects is both a concrete way of managing emotions and a playful attempt to move students out of their habitual ways of seeing/hearing criticism. Any object will work, and over the years, I have used Halloween monsters, bouncy balls, and plastic blobs among others. However, the toy cats seemed particularly effective. Perhaps the cats captured the irrepressible nature of the critical voice in a lighthearted way. 
Volume 28, 2018

http://journals.sfu.ca/cjsdw

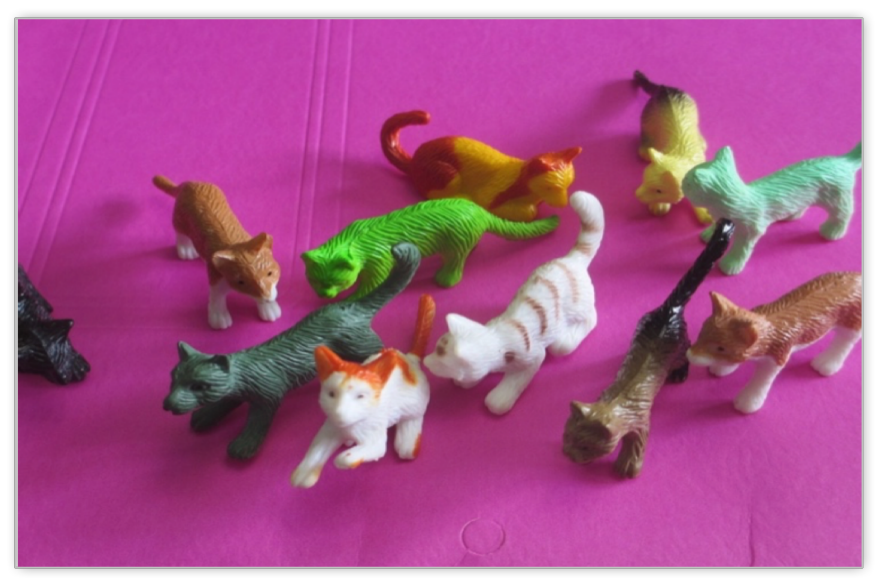

Figure 1 A clutter of cats (Photo by author)

\section{Students experiences of the pedagogical strategies}

Nineteen students (10 Masters and 9 PhDs) contributed their portfolio narratives (Assignment C) to my study. A research assistant recruited participants and collected the data and I was not involved in this process until well after the class closed. Participants came from Education, Pharmacy, Biology, Medicine and Health, Engineering, and Arts and Humanities. Assignment C, the portfolio narrative, was submitted a week after classes ended. Although the assignment was a reflection on aspects of the course they felt were threshold concepts, students were encouraged to discuss if they felt they had not learned or progressed as well and a few students made use of this opportunity. Before the assignment was due, we reviewed all the components of the course (nature of knowledge/academia, writing process, genre, rhetoric, discourse analysis, emotional intelligence) and they could write about any of these topics. In the portfolio narratives students chose to write about a range of ideas covered in the course that they identified as threshold concepts. However, by far, the most common threshold concept was recognising and dealing with criticism. Sixteen of the nineteen portfolio narratives explicitly mentioned criticism and recognised the importance of negotiating the resultant emotions to improve their writing practices. Two implicitly referred to the emotional nature of writing by using phrases like "writing is challenging" (Cully). Only one did not mention emotions at all and this student, I believe, was practicing emotional labour in her writing since she spoke about her emotions in class. I have grouped the responses from students below to correspond with the pedagogical strategies. 
Volume 28, 2018

http://journals.sfu.ca/cjsdw

\section{Free-writing}

All the students found free-writing useful for writing fluency and overcoming writing blocks. Only two students had used this method before but expressed that it had not worked for them in their previous attempts. This is possibly because without the discussion on internal criticism, they did not recognise the link between free-writing and emotions. In their portfolio narratives, many students indicated that they now understood the connection between emotions, being stuck with writing, and that free-writing was a useful technique to negotiate these emotions. These quotes are illustrative of many student comments:

Not only will free-writing benefit me academically but [will] also help me emotionally (Bodi) I have constantly practiced free writing. I turned off my computer screen and set the timer on for either five minutes or twenty-five minutes and started to write...For the first time in my life, I could get rid of a bad habit of writing and editing at the same time-a habit that had stopped me from writing continuously before (Harley)

\section{Dealing with negative internal dialogue}

How to negotiate negative internal dialogue was a strong theme in the assignments. Ten students made a point of including a section in their narratives on what they had learned about coping with emotions. Some talked about overcoming procrastination, others focused on what they recognized now as obstructive perfectionism created by external conditions rather than individual problems. Students wrote about their dominant critical voice and how they now had the tools to work with that voice.

Many students noted the change in their feelings about writing over the semester, for example:

I first noticed a change in my feelings and behaviors towards academic writing part way through the semester. The change in my attitude was also noted by my husband who said that I seemed happier writing and excited to talk about my writing experiences. What transformed my feelings and behavior towards academic writing? My attitude towards writing changed. (Amari) 
Notably, students recognized the role of emotions in behaviours such as procrastination and perfectionism:

I was anxious about writing, my writing potential, and the anticipated criticism related to my writing. I unconsciously wrote for, and according to, my inner critical voice. Overcoming my critical voice was a process that unfolded over the semester as I regained confidence when writing. I now believe I am a confident writer who has been equipped with the appropriate tools and strategies for inspiring, stimulating, and producing writing. Overcoming this inner voice has been a challenge but one with rewarding consequences...I am now the kind of writer who does not need to strive for perfection when writing. I do not focus on each word as I write. I do not attempt to edit my work sentence by sentence. My writing does not have to be perfect. (Sami)

There is an emergence of a philosophical approach as a way to deal with critical feedback, for example: "There will be people who will criticize my writing, but it is all part of the process" (Elli). In these narratives, students were more confident about acknowledging their emotions. They felt they could recognize emotions that stopped them from writing and could develop strategies to keep writing.

\section{Using objects to externalize feelings}

Five students (one male and four women) specifically mentioned using their toy cats as a way of coping with their internal critical voice. Their insights show that they were able to externalize their critical voice by using the cat but in a way that did not reinforce self-blame.

There were times when my critical thinker over took my creative thinker. To overcome that I made it a habit to pull out the cat and asked it to "be quiet." It really helped me. (Carson) Under the loving eye of my cat my emotional intelligence continues to be a work in progress as I believe it should be. (Maxi) 
My inner critical voice was still loud sometimes but because my screen was off, I could not see my piece of writing yet, I was able to shut off that voice. The little cat given to me by my instructor also helped me control my self-criticism whenever it appeared. I just wrote freely...all these messy and ugly pieces of writing no longer bothered me as they used to before. (Harley)

Amari and Blaine wrote the most about using their cats and included photographs in their assignments. Amari even named her cat:

Learning how to control my critical voice and when to listen to my critical voice is essential to my academic success. Early in the semester, I chose a small cat figurine, Rina, to represent my critical voice and I placed it beside my computer when writing. When my inner voice became too overwhelming, I told Rina, "No, I will listen to you after this section is finished." Incredibly, it temporarily silenced my critical voice. Listening to my critical voice was necessary during the latter stages of writing, but was counter-productive during the early stages of writing. (Amari)

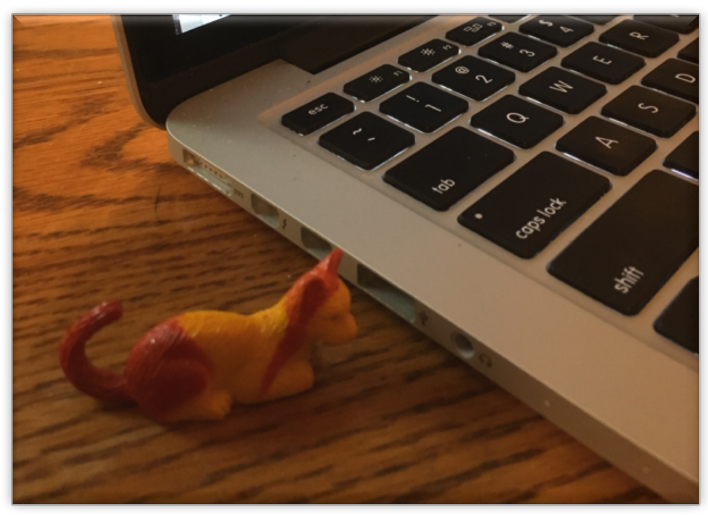

Figure 2: Amari's cat (Photo by Amari)

Blaine wrote that the course helped her to "handle criticism and failure" and taught her to understand "my critical voice and [to] start having a mature relationship with her." 
Volume 28, 2018

http://journals.sfu.ca/cjsdw

My "self-criticism" monster was waiting...to criticize me to the point of destruction. And to be honest, he did! But I didn't allow him to completely ruin me. I told myself that I learned...to handle criticism, and it is a time to practice those skills before hurting my selfconfidence. (Blaine)

During the course of the semester, she received negative feedback on a submission from her thesis to external reviewers. She expressed that she felt angry and "self-hatred" but instead of her emotions escalating, she chose to take acknowledge her feelings and take action:

I attempted to be mindful about all these negative feelings and thoughts in order to handle the emotional charge I got as a result of this unfair feedback...So I stopped labeling myself and beating myself up, and instead I started treating myself with respect. (Blaine)

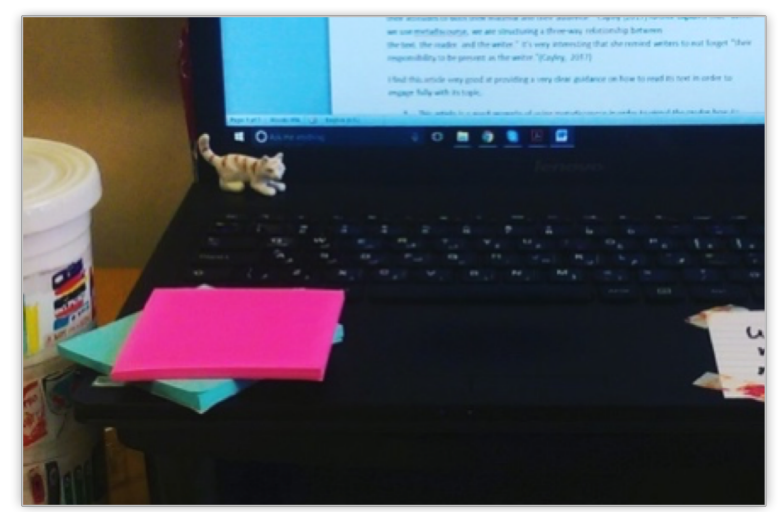

Figure 2 Blaine's cat (Photo by Blaine)

\section{Perceived Benefits of the Pedagogical Strategies}

In addition to references to the pedagogy, participants in the study commented on the implications of negotiating their emotions. 


\section{Balancing the individual with the contextual}

Students identified why it was important to them to negotiate their emotions. Overcoming isolation, a growing sense of agency, and a change in attitude towards writing emerged as themes. In the quote below, Harley connects to the social practice of writing, something she had not recognised before. The quote also illustrates her growing sense of agency and her willingness to bring others into her writing processes:

Before, I believed that writing is an individual work. I am a lonely writer who has to keep my writing for myself and by myself until it is all finished. I do my solo job and other people either correct it or criticize it as soon as I am done. Now I realize that writing is a team job. I engage with my supervisor and other graduate fellows since the first step of mind mapping and throughout the last step of revising/editing. (Harley)

Amari and Blaine are quite unequivocal about their growing sense of agency and Elli has repositioned herself:

If I choose, I can change the storyline which alters how I feel about the writing process, my role, and behavior. I have agency. (Amari)

My writing is not controlling me anymore. I'm the one who is in control, and having this power makes me feel confident and makes me more productive. (Blaine)

No matter what happens, whether I think my writing is going great or I feel stuck, I will be compassionate towards myself, and learn to silence that critical voice that tries to tell me, "YOU ARE NOT GOOD ENOUGH!” because “I AM!” (Elli, emphasis in original)

\section{Maintaining the playful}

There were expressions of positive emotions in the portfolio narratives, for example:

I am filled with excitement and anticipation. (Amari) 
I am treating my writing fairly; I try to love it "unconditionally"...And I realize that once you become a friend with your writing, you can have fun. (Blaine)

This final quote recognises the complex fluid nature of academic writing but also contains sense of being able to navigate whatever challenges lie ahead:

A feeling of confidence because I have completely changed my mind towards writing...I feel astonished how much my thoughts have changed in only 4 months of practice...I am now the kind of writer who will be constantly changing, because we are constantly changing...Writing academically is still challenging, but this course made me realize that it is not impossible. (Raya)

\section{Discussion}

The responses from students suggest that the techniques for engaging with emotions in writing were successful in helping students acknowledge and process their feelings. It also tells us that, for participants in this study, negotiating emotions are an important part of engagement with writing. Yet, I wondered whether students wrote about their writing emotions based on their understanding that it was an important issue for me, as the course instructor and assessor of assignments. There are a number of reasons why I gauge these perceptions to be authentic. First, students had the option to choose to report on any of the concepts covered in class (nature of knowledge, academic discourses, writing process, academic genres, rhetorical strategies, and disciplinary knowledge). Discussing emotions was only one aspect of the class and it was not an aspect I emphasized over others. Yet, 16 of the 19 students chose to write about emotions. There were variations in how the discussions on emotions were included in the assignments. Some students devoted most of their assignments to their experiences of writing emotions, while others mentioned emotions in a paragraph or two. Some also articulated their engagement with emotions much better than others. Second, I was surprised by the depth of discussions on emotions in the assignment, amazed that the cats had such an impact, and curious as to why this had emerged so strongly as a threshold concept in the assignments. The overwhelming attention given to emotions in the final assignment was unexpected and warranted further investigation. Third, the space afforded to emotions in the assignment indicates that students 
Volume 28, 2018

http://journals.sfu.ca/cjsdw

felt safe enough to write about their emotions in a context where there are few opportunities for graduate students to acknowledge their emotions. Overall, the assignments showed that many students felt strongly that dealing with their emotions was important to them for coping with critical feedback and moving forward with their writing.

Acknowledging the emotional journey students traverse is imperative. If, as Paré et al. (2011) suggest, supervisors are "deeply implicated in the shaping of [students as] rhetorical subjects" by helping students locate themselves as disciplinary members, publishable writers and academic scholars, we need to recognise how much emotions play a role (p. 233). By continuing to ignore the emotional side of writing, we encourage students to engage in debilitating emotional labour. Explicitly engaging with feelings, suggests to students that far from being unusual, their reactions are an inherent part of the writing process. However, as Burford (2017) has argued, we cannot ignore the increasing contextual pressures on students to be faultless, flawless, prolific and-in a wordperfect neoliberal subjects. An environment of critique and critical feedback further contribute to this mix. Students then internalise these messages into a seamless inner critical voice that demands perfection, but results in paralysis, particularly in their writing. The challenge is to help students to acknowledge the benefits of feedback and critique in a hypercritical environment, to recognise that although their internal voice is theirs, it also consists of influences around them, while at the same time developing some agency as an emerging scholar-writer in a discourse.

What are the broader implications for explicit pedagogy around writing emotions? First, the danger of not engaging with emotions is that students see emotions as individualised (Williams \& Lee, 1999). They view emotions as "their" problem rather than a collective result of stressful and high risk writing practices. The danger is that students, then, cannot perceive of themselves as part of a community or a larger narrative and only see themselves as individuals in deficit. Second, in an environment where criticism is core business, without discursive emotional intelligence, we create the conditions for students to focus their attention on avoiding criticism at the expense of creativity, originality and imagination (Cameron, et al., 2009; James \& Brookfield, 2014). If we want students to embrace playfulness in their writing, we first need to acknowledge the emotional environment within which they work. Constantly being on guard, under surveillance and being criticised creates writers who are cautious, who aim to protect themselves and who seek conformity. By letting criticism dominate uncontrolled, students are less likely to take risks, extend themselves or be innovative in their writing. Finally, as Burke (2015, p. 400) states emotions are a "critical resource to reflexively develop collective and ethical participation in pedagogical spaces." Emotions are 
relational and the product of social relationships and when we enlarge our teaching spaces to include emotions, we counter the "unchecked individualization, increasingly embedded in hegemonic discourses of neoliberalism, which push us further from a sense of our human interdependence, connectivity and social belonging" (Burke, 2015, p. 388). In other words, when we include emotions we encourage students to feel connected and part of a community.

\section{Conclusion}

The participants in this study echo the research literature in claiming that writing is an emotionallydriven activity and that feedback from supervisors is a main source of anxiety. The pedagogical strategies I have presented here-free-writing, dealing with negative internal dialogue, using objects to externalise feelings which build toward a discursive emotional intelligence-are mechanisms to achieve this balancing act. Controlling their negative internal dialogue became a key strategy for negotiating emotions for students in this study. By acknowledging negative internal dialogue, many were able to develop writing fluency, make the most of the feedback, and maintain a sense of self even in the face of severe criticism. The cats provided a fun, tangible way to deal with emotions that promoted self-care, self-compassion and creativity. Through recognising and negotiating their emotions, these participants transformed their emotional reactions to writing. Although many still acknowledged that writing was challenging and emotional, they felt they were able to cope better with their feelings by the end of the course. This is evidence of more than a change of attitude, but rather a shift towards agency where the writer is no longer passively at the receiving end of feedback but is an active participant in negotiating how that critique will be absorbed and used.

\section{Endnotes}

1. Correspondence concerning this article should be addressed to Cecile Badenhorst cbadenhorst@mun.ca

2. These quotes come from Assignment A which formed part of the data set for the research project. Names have been changed to protect participants' privacy and anonymity.

\section{Acknowledgements}


Volume 28, 2018

http://journals.sfu.ca/cjsdw

I would like to extend my appreciation and gratitude to the students who participated in this project, to Xiaolin Xu for her research assistance, to the anonymous reviewers who contributed substantially to the final version of this paper, and to the Faculty of Education, Memorial University for providing the research funding. MUN ICEHR granted ethical approval for this study. 
Volume 28, 2018

http://journals.sfu.ca/cjsdw

\section{References}

Aitchison, C., \& Mowbray, S. (2013). Doctoral women: Managing emotions, managing doctoral studies. Teaching in Higher Education, 18(8), 859-870. doi: 10.1080/13562517.2013.827642

Aitchison, C., Catterall, J., Ross, P., \& Burgin, S. (2012). “Tough love and tears”: Learning doctoral writing in the sciences. Higher Education Research \& Development, 31(4), 435-447. doi: 10.1080/07294360.2011.559195

Alexander, K. P. (2011). Successes, victims, and prodigies: 'Master' and 'little' cultural narratives in the literacy narrative genre. College Composition and Communication, 62(4), 608-633.

Badenhorst, C.M., Moloney, C., Rosales, J., \& Dyer, J. (2012). Graduate research writing: A pedagogy of possibility. LEARNing Landscapes, 6(1), 63-80.

Badenhorst, C.M., Moloney, C., Rosales, J., \& Dyer, J. (2016). Thinking through play: "Visual” approaches to post/graduate research writing. In C.M. Badenhorst, \& C. Guerin (Eds.), Research literacies and writing pedagogies for masters and doctoral writers (pp. 335-355). Studies in Writing Series, Leiden, Amsterdam: Brill Publishing.

Badenhorst, C.M., Moloney, C., Rosales, J., Dyer, J. \& Murray, M. (2015). Thinking creatively about research. In T. Lillis, K. Harrington, M. Lea \& S. Mitchell (Eds.), Working with academic literacies: Research, theory, design (pp. 227-254). WAC Clearinghouse/Parlor Press: South Carolina.

Badenhorst, C.M., Moloney, C., Rosales, J., Dyer, J. \& Ru, C. (2014). Beyond deficit: Graduate student research writing pedagogies. Teaching in Higher Education, 20(1), 1-11.

Barnacle, R., \& Mewburn, I. (2010). Learning networks and the journey of 'becoming doctor'. Studies in Higher Education, 35(4), 433-444. doi: 10.1080/13562517.2014.945160

Beard, C., Clegg, S., \& Smith, K. (2007). Acknowledging the affective in higher education. British Educational Research Journal, 33, 235-252. doi:10.1080/01411920701208415

Bosanquet, A., \& Cahir, J. (2016). “What feelings didn't I experience!”: Affect and identity in PhD writing. In C.M. Badenhorst \& C. Guerin (Eds.), Research literacies and writing pedagogies for masters and doctoral writers (pp. 132-148). Studies in Writing Series, Leiden, Amsterdam: Brill Publishing.

Brown, B. (2010, June). The power of vulnerability. [Video file]. https://www.ted.com/talks/brene_brown_on_vulnerability

Brown, L., \& Watson, P. (2010). Understanding the Experiences of Female Doctoral Students. Journal of Further and Higher Education, 34(3), 385 404. doi: 10.1080/0309877X.2010.484056 
Volume 28, 2018

http://journals.sfu.ca/cjsdw

Burford, J. (2017). Conceptualising doctoral writing as an affective-political practice. International Journal of Doctoral Studies, 12. Https://ijds.org/Volume12/IJDSv12p017-032Burford3192.pdf

Burke, P.J. (2015). Re/imagining higher education pedagogies: gender, emotion and difference. Teaching in Higher Education, 20(4), 388-401. doi: 10.1080/13562517.2015.1020782

Caffarella, R.S., \& Barnett, B.G. (2000). Teaching doctoral students to become scholarly writers: The importance of giving and receiving critiques. Studies in Higher Education, 21(1), 39-52. doi:10.1080/030750700116000

Cameron, J, Nairn, K., \& Higgins, J. (2009). Demystifying academic writing: Reflections on emotions, know-how and academic identity. Journal of Geography in Higher Education, 33(2), 269-284. doi: 10.1080/03098260902734943

Collins, J. (2015). Writer's forum - Writing for publication while in graduate school: An accessible reality. New horizons in Adult Education \& Human Resource development, 27(1), 51-55. doi:10.1002/nha3.20094

Cotterall, S. (2013). More than just a brain: Emotions and the doctoral experience. Higher Education Research \& Development, 32(2), 174-187. doi: 10.1080/07294360.2012.680017

Doloriert, C., Sambrook, S., \& Stewart, J. (2012). Power and emotion in doctoral supervision: Implications for HRD. European Journal of Training and Development, 36(7), 732-750. doi: $10.1108 / 03090591211255566$

Elbow, P. (1981). Power Writing. Oxford: Oxford University Press.

Emmons, K. (2003). Rethinking genres of reflection: Student portfolio cover letters and the narrative of progress. Composition Studies, 31(1), 43-62.

Friedrich-Nel, H.S., \& Mac Kinnon, J.L. (2015). Formative assessment in doctoral education. Journal for New Generation Sciences, 13(2), 1-14.

Fulford, A. (2009). Ventriloquizing the voice: Writing in the university. Journal of Philosophy of Education, 43(2), 223-237. doi: 10.1111/j.1467-9752.2009.00685.x

Goleman, D. (1997). Emotional intelligence. New York: Bantam Books.

Hey, V. (2011). Affective asymmetries: Academics, austerity and the mis/recognition of emotion. Contemporary Social Science, 6(2), 207 222. doi:10.1080/21582041.2011.583486

Huerta, M., Goodson, P., Beigi, M., \& Chlup, D. (2017). Graduate students as academic writers: Writing anxiety, self-efficacy and emotional intelligence. Higher Education Research \& Development, 36(4), 716-729. doi: 10.1080/07294360.2016.1238881 
Volume 28, 2018

http://journals.sfu.ca/cjsdw

James, A., \& Brookfield, S.D. (2014). Engaging imagination: Helping students to become creative and reflective thinkers. San Francisco, CA: John Wiley \& Sons.

Jarzabkowski, L. (2001). Emotional labour in educational research. Queensland Journal of Educational Research, 17(2), 123137.

Kamler, B. (2008). Rethinking doctoral publication practices: Writing from and beyond the thesis. Studies in Higher Education, 33(3), 283-294. doi: 10.1080/03075070802049236

Kamler, B., \& Thomson, P. (2006). Helping doctoral students write. London: Routledge.

Lavelle, E., \& Bushrow, K. (2007). Writing approaches of graduate students. Educational Psychology, 27(6), 807-822. doi: 10.1080/01443410701366001

Leathwood, C., \& Hey, V. (2009). Gender/ed discourses and emotional sub-texts: Theorising emotion in UK higher education. Teaching in Higher Education 14(4), 429-440. doi:

$10.1080 / 13562510903050194$

Maher, M. A., Feldon, D. F., Timmerman, B. E., \& Chao, J. (2014). Faculty perceptions of common challenges encountered by novice doctoral writers. Higher Education Research \& Development, 33(4), 699-711. doi: 10.1080/07294360.2013.863850

Maisel, E. (2007). Toxic criticism. New York: McGraw-Hill.

Martinez, C. T., Kock, N., \& Cass, J. (2011). Pain and pleasure in short essay writing: Factors predicting university students' writing anxiety and self-efficacy. Journal of Adolescent and Adult Literacy, 54, 351-360. doi: 10.1598/JAAL.54.5.5

McAlpine, L., Paulson, J., Gonsalves, A., \& Jazvac-Martek. M. (2012). Untold doctoral stories: Can we move beyond cultural narratives of neglect? Higher Education Research \& Development, 31(4), 511 523. doi: 10.1080/07294360.2011.559199

Neff, K. (2013, February). The space between self-esteem and self-compassion. [Video file]. https://www.youtube.com/watch?v=IvtZBUSplr4

Onwuegbuzie, A.J., \& Collins, K.M.T. (2001). Writing apprehension and academic procrastination among graduate students. Perceptual and Motor Skills, 92(2), 560-562. doi:

10.2466/pms.2001.92.2.560

Paré, A. (2011). Speaking of writing: Supervisory feedback and the dissertation. In L. McAlpine \& C. Amundsen (Eds.), Doctoral education: Research-based strategies for doctoral students, supervisors and administrators (pp. 59-74). Dordrecht, The Netherlands: Springer.

Paré, A., Starke-Meyerring, D., \& McAlpine, L. (2011). Knowledge and identity work in the supervision of doctoral student writing: Shaping rhetorical subjects. In D. Starke-Meyerring, A. 
Volume 28, 2018

http://journals.sfu.ca/cjsdw

Paré, N. Artemeva, M. Horne \& L. Yousoubova (Eds.), Writing in knowledge societies (pp. 215236). Fort Collins, Colorado: The WAC Clearinghouse and Parlor Press

Prior, P., \& Shipka, J. (2003). Chronotopic lamination: Tracing the contours of literate activity. In C. Bazerman \& D. Russell (Eds.), Writing Selves/Writing Societies (pp. 180-238). Colorado State University: WAC Clearinghouse.

Rowe, A.D., Fitness, J., \& Wood, L.N. (2014). The role and functionality of emotions in feedback at university: A qualitative study. Australian Education Research, 41, 283-309. doi:

10.1007/s13384-013-0135-7

Sawir, E., Marginson, S., Deumert, A., Nyland, C., \& Ramia, G. (2008). Loneliness and international students: An Australian study. Journal of Studies in International Education, 12(2), 148-180. doi: $10.1177 / 1028315307299699$

Seear, K., \& McLean, K. (2008). Breaking the silence: The role of emotional labour in qualitative research. Paper presented at the Australian Sociological Association Annual Conference, Melbourne, Australia, December 25.

Stubb, J., Pyhältö, K., \& Lonka, K. (2011). Balancing between inspiration and exhaustion: PhD students' experienced socio-psychological well-being. Studies in Continuing Education, 33(1), 3350. doi: 10.1080/0158037X.2010.515572

Värlander, S. (2008). The role of students' emotions in formal feedback situations. Teaching in Higher Education, 13(2), 145-156. doi: 10.1080/13562510801923195

Wall, S. (2008). Of heads and hearts: Women in doctoral education at a Canadian university. Women's Studies International Forum, 31(3), 219-228. doi: 10.1016/j.wsif.2008.04.007

Wellington, J. (2010). More than a matter of cognition: An exploration of affective writing problems of post-graduate students and their possible solutions. Teaching in Higher Education, 15(2), 135150. doi: $10.1080 / 13562511003619961$

Williams, C. \& Lee, A. (1999). Forged in fire: Narratives of trauma in PhD supervision pedagogy. Southern Review: Communication, Politics \& Culture, 32(1), 6-26.

$\mathrm{Xu}, \mathrm{L}$. (2016). Written feedback in intercultural doctoral supervision: A case study. Teaching in Higher Education, 22(2), 239-255. doi: 10.1080/13562517.2016.1237483

Young, P. (2000). "I might as well give up": Self-esteem and mature students' feelings about feedback on assignments. Journal of Further \& Higher Education, 24(3), 409-418. doi: http://dx.doi.org/10.1080/030987700750022325 